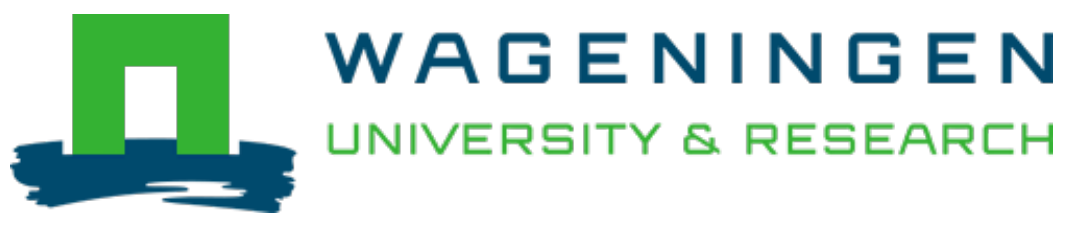

\title{
Food microbiology and hygiene
}

Encyclopedia of human biology. Vol. 3

Rombouts, F.M.; Nout, M.J.R.

This publication is made publicly available in the institutional repository of Wageningen University and Research, under the terms of article $25 \mathrm{fa}$ of the Dutch Copyright Act, also known as the Amendment Taverne. This has been done with explicit consent by the author.

Article 25 fa states that the author of a short scientific work funded either wholly or partially by Dutch public funds is entitled to make that work publicly available for no consideration following a reasonable period of time after the work was first published, provided that clear reference is made to the source of the first publication of the work.

This publication is distributed under The Association of Universities in the Netherlands (VSNU) 'Article $25 \mathrm{fa}$ implementation' project. In this project research outputs of researchers employed by Dutch Universities that comply with the legal requirements of Article $25 \mathrm{fa}$ of the Dutch Copyright Act are distributed online and free of cost or other barriers in institutional repositories. Research outputs are distributed six months after their first online publication in the original published version and with proper attribution to the source of the original publication.

You are permitted to download and use the publication for personal purposes. All rights remain with the author(s) and / or copyright owner(s) of this work. Any use of the publication or parts of it other than authorised under article $25 \mathrm{fa}$ of the Dutch Copyright act is prohibited. Wageningen University \& Research and the author(s) of this publication shall not be held responsible or liable for any damages resulting from your (re)use of this publication.

For questions regarding the public availability of this publication please contact openscience.library@wur.nl 


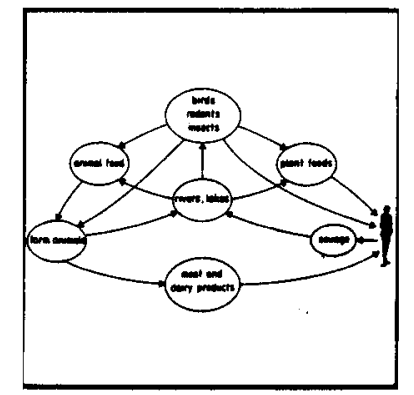

\title{
Food Microbiology and Hygiene
}

\author{
FRANK M. ROMBOUTS and ROBERT NOUT, Wageningen
} Agricultural University

I. Contamination and Spoilage

II. Food-Borne Pathogens

III. Fermentation

IV. Food Processing and Preservation

V. Microbiological Control and Monitoring

\section{Glossary}

Chelate Strong binding by complex formation Code of hygienic practice Describes good manufacturing practices to ensure microbiologically safe products of high quality

Food-borne pathogens Microbes that can cause food infection or food intoxication through their activity in the host or in the food

Food irradiation Treatment of food with ionizing radiation to extend shelf life and/or increase food safety

Hazard analysis critical control points Means of identifying and controlling the microbiologically important hazards in a food operation

Predictive food microbiology Prediction of shelf life or microbiological quality of foods by the use of a data base and mathematical models

Spoilage association Typical set of microbes that come to dominance when a food is allowed to spoil

FOOD MICROBIOLOGY AND HYGIENE belong to that branch of microbiology which deals with the control of microorganisms during the production, processing, storage, and distribution of food. Three categories of microorganisms can be distinguished. Two of these (i.e., spoilage and pathogenic organisms). are controlled through the prevention of contamination and proliferation. A third group, the fermentation organisms, is stimulated, or deliberately added as a starter culture to obtain fermented foods. Food microbiologists and hygienists are concerned with the microbial quality and safety of existing and new food products.

\section{Contamination and Spoilage}

Our food is derived from plants and animals, and these are naturally contaminated with microorganisms. Sound tissues of plants and animals are largely sterile, but large numbers of a wide variety of bacteria, yeasts, molds, and viruses occur on the surface of plants and on the coat, mucous membranes, and intestine of animals.

Other sources of contamination are harvesting, transport and processing equipment, and personnel handling raw materials and food products anywhere along the food chain.

Not all microorganisms entering food are of importance. The chemical nature of the product and a number of environmental factors determine which kinds of microorganisms will grow and cause spoilage. In this relationship the term "spoilage association" is frequently used and refers to the typical set of microorganisms which will come to dominance when a food product is allowed to spoil under certain environmental conditions. A few examples are given in Table I.

Three groups of factors are involved in food spoilage: (1) intrinsic factors (the physical and chemical properties of the food), (2) extrinsic factors (environmental factors, such as temperature, humidity, and the presence of oxygen), and (3) implicit factors (physiological and ecological features that enable microorganisms to respond to selective factors 1 and 2).

\section{A. Intrinsic Factors}

Both the speed and the type of spoilage are determined by a number of physical and chemical param- 
TABLE I Spoilage Associations of Some Foods at Ambient Temperature

\begin{tabular}{|c|c|c|}
\hline Food & Characteristics & $\begin{array}{l}\text { Spoilage } \\
\text { microorganisms }\end{array}$ \\
\hline Fresh meat, fish & $\begin{array}{l}\text { Moist, proteins, low in } \\
\text { carbohydrates }\end{array}$ & $\begin{array}{l}\text { Pseudomonas, } \\
\text { Acinetobacter, } \\
\text { Alteromonas, } \\
\text { Proteus, } \\
\text { Enterobacter, } \\
\text { Aeromonas }\end{array}$ \\
\hline Raw milk & $\begin{array}{l}\text { Lactose, proteins, } \\
\text { vitamins, minerals }\end{array}$ & $\begin{array}{c}\text { Lactococcus, } \\
\text { Streptococcus, } \\
\text { Lactobacillus }\end{array}$ \\
\hline $\begin{array}{l}\text { Fruits, fruit } \\
\text { juices }\end{array}$ & $\begin{array}{l}\text { Fermentable sugars, } \\
\text { low pH }\end{array}$ & $\begin{array}{l}\text { Saccharomyces, } \\
\text { Candida, } \\
\text { Hanseniaspora } \\
\text { and other } \\
\text { yeasts; } \\
\text { Penicillium, } \\
\text { Botrytis, and } \\
\text { other molds; } \\
\text { lactic acid } \\
\text { bacteria }\end{array}$ \\
\hline $\begin{array}{l}\text { Bread, bakery } \\
\text { products }\end{array}$ & $\begin{array}{l}\text { Fairly dry, rich in } \\
\text { carbohydrates }\end{array}$ & $\begin{array}{l}\text { Rhizopus, } \\
\text { Penicillium, } \\
\text { Geotrichum, } \\
\text { Bacillus }\end{array}$ \\
\hline Bacon, ham & $\begin{array}{l}\text { Fairly dry, proteins, } \\
\text { low in carbohydrates }\end{array}$ & $\begin{array}{l}\text { Micrococcus, } \\
\text { Lactobacillus, } \\
\text { Streptococcus, } \\
\text { Bacillus, } \\
\text { yeasts, and } \\
\text { molds }\end{array}$ \\
\hline Mineral waters & $\begin{array}{l}\text { Extremely low in } \\
\text { nutrients }\end{array}$ & $\begin{array}{c}\text { Flavobacterium, } \\
\text { Cytophaga, } \\
\text { Nocardia, } \\
\text { Alcaligenes, } \\
\text { Pseudomonas }\end{array}$ \\
\hline
\end{tabular}

eters of food products. Most important are water activity, $\mathrm{pH}$, the presence of oxygen and redox potential, the presence of nutrients, and natural antimicrobial systems.

\section{Water Activity}

Water activity $\left(a_{\mathrm{w}}\right)$ determines the availability of water to microorganisms for metabolism and growth. The $a_{\mathrm{w}}$ is equal to the ratio of the equilibrium vapor pressure of a food to that of pure water, and is slightly temperature dependent. In products with a low $a_{\mathrm{w}}$, limitation of diffusional properties of nutrients can become an additional factor limiting growth.

Most perishable foods (e.g., fresh meat, fish, and milk) have an $a_{\mathrm{w}}$ close to 1 (i.e., $>0.98$ ) and spoil rapidly by bacteria requiring a high $a_{\mathrm{w}}$ (e.g., Pseudomonas, Acinetobacter, Enterobacter, Proteus, and Bacillus spp. Products with an $a_{\mathrm{w}}$ of 0.95 0.90 (e.g., dry ham, medium-age cheese, and many types of sausages) are likely to spoil by bacteria such as Micrococcus, Lactobacillus, Bacillus, yeasts (e.g., Pichia, Candida, and Saccharomyces), and fungi (e.g., Rhizopus and Mucor). Products with an $a_{\mathrm{w}}$ below 0.90 (e.g., crude smoked ham and salami-type sausage) spoil more slowly, and deterioration is usually caused by certain yeast and molds. Yeasts such as Zygosaccharomyces rouxii, which can grow at a high sugar concentration such as in honey or in fruit concentrates $\left(a_{w}\right.$ of $0.65-$ 0.62 ), are termed osmophiles. Bacteria resisting high salt concentrations are called halophiles. They have an absolute requirement for higher concentrations of sodium chloride, as might be encountered in meat-curing brines.

\section{2. $\mathrm{pH}$}

The $\mathrm{pH}$ value of most foods is in the range of 3.57.0. Most vegetables, cereal products, and fresh products of animal origin have a $\mathrm{pH}$ of around 6.0. If other factors (e.g., $a_{\mathrm{w}}$ ) permit, these products spoil more or less rapidly through bacteria, which outgrow yeasts and molds at this $\mathrm{pH}$. More acidic products (e.g., fruits, fruit juices, soft drinks, tomato products, beer, and wine) can spoil by yeasts, molds, and acid-tolerant bacteria.

Not only low pH, but also the presence of organic acids, plays a role in shelf life. Acetic acid is particularly effective against molds, yeasts and lactobacilli, and is a valuable preservative ingredient in acidic products such as dressings, mayonnaise, and mayonnaise-based salads.

\section{Oxygen and Redox Potential}

Products in which there is free access of air spoil primarily by aerobic organisms, which require oxygen for growth. This is true for the unprotected surfaces of many products, including meat, fish, and chicken, and for certain liquid foods (e.g., milk). Rapid growth and consumption of oxygen can lead to a depletion of dissolved oxygen and a decrease in redox potential. This can cause a shift in microflora toward facultative aerobic and strictly anaerobic microorganisms, which do not need oxygen, as is often the case in milk spoilage at ambient temperature, when lactic acid bacteria and occasionally butyric acid bacteria might finally dominate. 


\section{Chemical Composition}

Spoilage is also determined by food as a substrate and a nutrient medium for microorganisms. Sugars, as a carbon source, are present in abundance in fruit juices and these are fermented to ethanol and other products, when yeast spoilage occurs. Ethanol can, in turn, serve as a carbon source for acetic acid bacteria to produce acetic acid, when sufficient oxygen is available. In tomato juice and vegetable juices, in which the $\mathrm{pH}$ is somewhat higher, lactic acid bacteria ferment the sugars to lactic acid. Fresh meat is, above all, a source of proteins, and the spoilage flora consists of gram-negative bacteria which are powerfully proteolytic. Proteolysis and metabolism of amino acids and peptides by these bacteria result in sliminess and off-odors caused by ammonia, amines, hydrogen sulfide, mercaptans, and other products. Foods with a high fat content (e.g., butter, margarine, and lard) can be spoiled by bacteria, molds, and yeasts which are lipolytic and cause rancidity through the liberation of fatty acids and accumulation of aldehydes and ketones.

\section{Antimicrobial Systems}

In both plant and animal products antimicrobial compounds occur, about which there is an increasing interest among food microbiologists. In plant products these are usually small molecules such as acids (e.g., salicylic acid in raspberries and benzoic acid in cranberries), phenolic compounds (e.g., tannin in walnuts and cocoa), alkaloids, and essential oils. These compounds work cooperatively with physical barriers such as peels, shells, skins, hulls, and rinds.

In the albumin of the avian egg, a whole series of proteins has antimicrobial properties, such as lysozyme (which causes lysis), ovotransferrin (which chelates ferric ions), ovidin (which chelates biotin), and ovoinhibitor (which inhibits several proteases).

Milk contains several antimicrobial systems, such as antibodies and a number of nonantibody proteins (e.g., lysozyme, lactoferrin, xanthine oxidase, and lactoperoxidase). With thiocyanate and hydrogen peroxide, both present in milk, lactoperoxidase forms the antimicrobial lactoperoxidase system. Lactoperoxidase catalyzes the oxydation of thiocyanate by hydrogen peroxide. The major oxidation product, hypothiocyanate, is an effective antimicrobial agent. It has recently been proposed to exploit the lactoperoxidase system in the preservation of raw milk by the addition of extremely small quantities of thiocyanate and hydrogen perox- ide, in situations in which refrigeration is not possible because of a lack of electricity.

\section{B. Extrinsic Factors}

Extrinsic factors are temperature, relative humidity, and the gaseous environment of storage. Relative humidity and gaseous environment (e.g., oxygen and carbon dioxide) are at interplay with the concomitant intrinsic factors $a_{\mathrm{w}}$ and oxygen, described in Sections I,A,1 and I,A,3. The most important extrinsic factor is storage temperature. $\mathrm{Al}-$ though microbiological spoilage occurs over the wide range of temperatures of -5 to $60^{\circ} \mathrm{C}$, low temperatures are effective in delaying spoilage. Microorganisms are killed at high temperatures, such as those used in pasteurization $\left(<100^{\circ} \mathrm{C}\right)$ and sterilization $\left(110-144^{\circ} \mathrm{C}\right)$ processes. With respect to the temperature requirement for growth, several groups of microorganisms exist (Table II). The storage temperature selects for those organisms with the highest growth rate at the temperature considered.

\section{Implicit Factors}

Specific growth characteristics of microorganisms (e.g., specific growth rate, growth factor requirements, and accumulation of end products) and mutual influences, antagonistic or synergistic, among organisms are commonly referred to as implicit factors of food spoilage.

The speed and the type of food spoilage, as well as microorganisms involved, are determined by the interplay of intrinsic, extrinsic, and implicit factors. Food spoilage is therefore an intricate ecological process.

\section{Food-Borne Pathogens}

Food can serve as a vehicle or growth medium for pathogens (e.g., bacteria, molds, viruses, amebae,

TABLE II Temperature Requirements of Microorganisms

\begin{tabular}{|c|c|c|c|}
\hline Group & $\begin{array}{l}\text { Minimum } \\
\text { temperature } \\
\left({ }^{\circ} \mathrm{C}\right)\end{array}$ & $\begin{array}{l}\text { Optimum } \\
\text { temperature } \\
\left({ }^{\circ} \mathrm{C}\right)\end{array}$ & $\begin{array}{l}\text { Maximum } \\
\text { temperature } \\
\left({ }^{\circ} \mathrm{C}\right)\end{array}$ \\
\hline Psychrophiles & -10 & $10-15$ & $18-20$ \\
\hline Psychrotrophs & -5 & $25-30$ & 35 \\
\hline Mesophiles & $5-10$ & $30-45$ & 47 \\
\hline Thermotrophs & $20-25$ & $42-46$ & $50-55$ \\
\hline Thermophiles & $40-45$ & $55-75$ & $60-90$ \\
\hline
\end{tabular}


and parasitic worms). A distinction can be made between food-borne infections and microbial food intoxications, depending on whether the pathogen itself or its toxic product (a microbial toxin, produced in the food) is the causal agent of disease. Table III presents the most important bacterial food-borne pathogens. Food infections caused by Salmonella and Campylobacter occur most frequently.

\section{A. Salmonella}

Salmonella is a food-borne pathogen causing gastroenteritis, an infection with diarrhea, vomiting, abdominal pains, and usually fever. The high incidence of this disease is a result of the existence of infection and contamination cycles, which have been intensively studied (Fig. 1). The primary habitat of Salmonella is the gut of humans and warmblooded animals. Human patients and carriers can excrete large numbers of Salmonella with their feces, from which they are transmitted to surface waters (e.g., rivers and lakes). These function as sources of infection for farm animals, rodents, birds, and insects, which carry the infection either directly or indirectly, via contamination of animal feed, to the farm. During the transport and industrial slaughtering of pigs, poultry, and cattle, cross- contamination occurs, so that meat from Salmonella-free animals is also contaminated. The contamination level of broilers, for example, is often higher than $50 \%$.

Contaminated meat and poultry are distributed to restaurants and catering facilities, and via retail outlets to homes. Through cross-contamination of equipment, surfaces, and hands and improper cleaning, other foods can become contaminated. Outgrowth to infectious dose occurs when heating, cooling, and cold storage are not adequate.

A rather small number of the 2200 serotypes of Salmonella are frequently encountered agents of gastroenteritis, among others: $S$. typhimurium, $S$. virchov, $S$. brandenburg, $S$. infantis, and $S$. panama. Of particular importance is the recent emergence, in both the United States and Europe, of a few phage types of $S$. enteritidis that cause severe gastroenteritis and that have been isolated from hens' eggs, a food product that was hitherto considered to be essentially free of pathogens. Evidence is accumulating that these phage types are capable of causing the transovarian contamination of eggs, and can therefore be spread by vertical transmission.

The incidence of Salmonella food infections is not accurately known, but is estimated by the World Health Organization (WHO) to be on the or-

TABLE III Bacterial Agents of Food-Borne Diseases

\begin{tabular}{llll}
\hline Organism & Pathogenicity & $\begin{array}{l}\text { Incubation } \\
\text { period } \\
\text { (hours) }\end{array}$ & $\begin{array}{l}\text { Duration of } \\
\text { disease } \\
\text { (days) }\end{array}$ \\
\hline Salmonella & Infection & $6-36$ & $1-7$ \\
Shigella & Infection & $6-12$ & $2-3$ \\
Escherichia coli & Infection & $12-72$ & $1-7$ \\
Yersinia enterocolitica & Infection & $24-36$ & $3-5$ \\
Campylobacter jejuni & Infection & $3-5$ (days) & $5-7$ \\
Listeria monocytogenes & Infection & Variable & - a \\
Vibrio parahaemolyticus & Infection & $2-48$ & $2-5$ \\
Aeromonas hydrophila & Infection & $2-48$ & $2-7$ \\
Staphylococcus aureus & Toxin in food & $2-6$ & $\leq 1$ \\
Clostridium botulinum & Toxin in food & $12-96$ & $1-8$ \\
Clostridium perfringens & Toxin in intestine & $8-22$ & $1-2$ \\
Bacillus cereus & Toxin in food & $1-5$ & $\leq 1$ \\
Bacillus cereus & Toxin in intestine & $8-16$ & $>1$ \\
\hline
\end{tabular}

affects people with a predisposing factor; high mortality rate.

${ }^{b}$ High mortality rate; complete convalescence takes 6-8 months.

c Emetic type

${ }^{d}$ Diarrhoeal type 


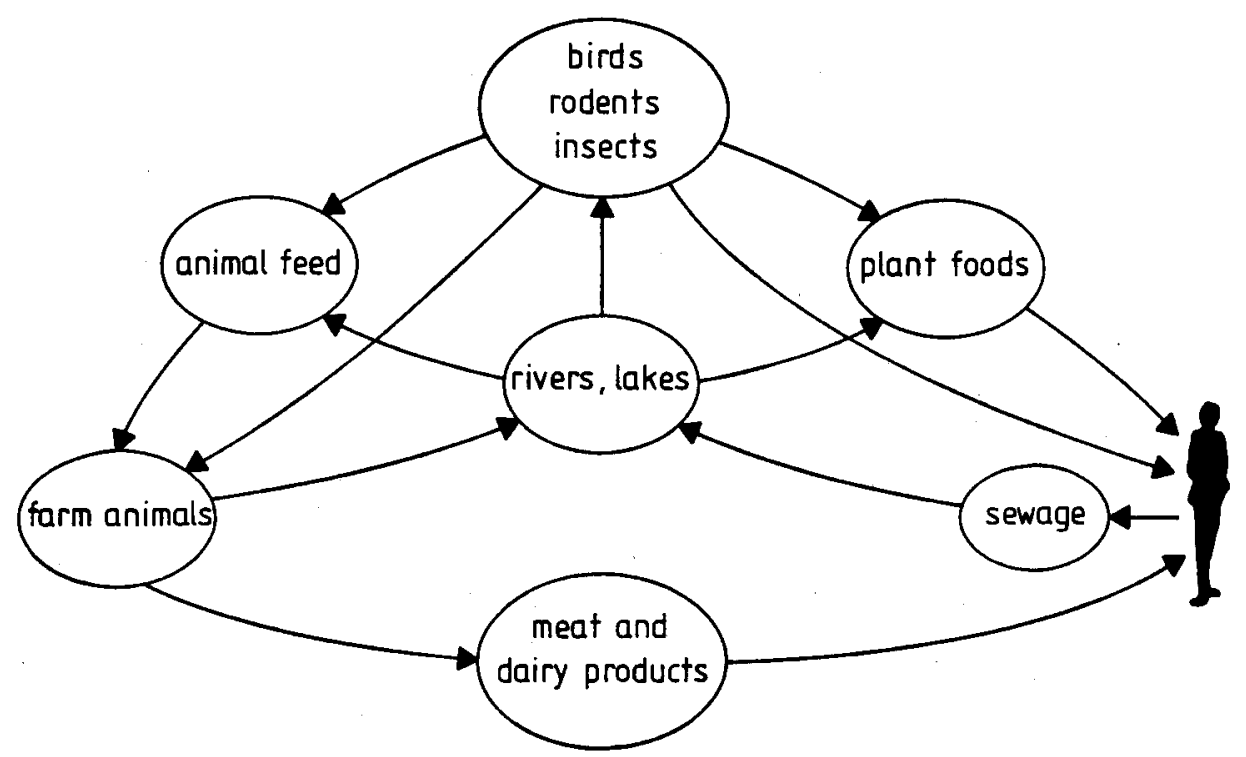

FIGURE 1 Contamination cycles of Salmonella

der of 1 million, with several hundred deaths per year in Europe alone. The WHO strongly recommends an integrated approach to reduce the contamination levels of meat and poultry. Effective control should be possible by agricultural production free of infection, supplemented by hygiene efforts in food processing and preparation and by general preventive measures (e.g. heat, refrigeration, and chemical treatment or irradiation). [See $S_{A L}$ MONELLA.]

\section{B. Campylobacter jejuni}

This spirally curved gram-negative bacterium appears to be responsible for $8-10 \%$ of all cases of acute enteritis diagnosed in The Netherlands. Campylobacteriosis can occur even more frequently than salmonellosis, which is diagnosed in about 5\% of cases, and the symptoms of disease are at least equally serious. Because of lack of adequate isolation procedures this organism was only recognized around 1975 as an important agent of enteritis. Food of animal origin is often incriminated in campylobacteriosis (e.g., poultry in The Netherlands and raw milk in England).

It is not likely that the same contamination cycles exist for Campylobacter as for Salmonella. Important differences between the two pathogens are that Campylobacter does not grow below $25^{\circ} \mathrm{C}$ and is less widespread in the environment. However, it has been claimed that Campylobacter can persist in coccoid nonculturable forms which are still viable and can cause infections.

\section{Listeria monocytogenes}

This gram-positive rod-shaped bacterium is an environmental organism, capable of causing listeriosis. This disease typically affects people with a predisposing factor (e.g., immunosuppressed people, pregnant women, and neonates) and causes serious symptoms, such as meningitis, encephalitis, and abortion. Although much is unknown about its epidemiology, epidemics of listeriosis have been linked to food consumption in recent years. Food products incriminated in outbreaks in the United States and Canada were presumably recontaminated pasteurized milk, refrigerated coleslaw, and Mexican-style soft cheese. Although listeriosis does not occur frequently, foods are under intense scrutiny for Listeria, since mortality rates in the epidemics mentioned were extremely high (i.e., about 30\%).

\section{Other Food-Borne Pathogens}

\section{Escherichia coli}

Escherichia coli is normally a harmless bacterium, with the intestine as its primary habitat. However, some strains (e.g., enteropathogenic, enteroinvasive, and enterotoxigenic) cause food infections, especially in babies and young children. 
Apparently, these strains occur regularly in low numbers in food products and can incidentally grow to high numbers, setting off food infections. Recently enterohemorrhagic $E$. coli has caused severe outbreaks of infection due to meat products. Because of the high fatality rate $(2-20 \%)$ it is now an organism of major concern.

\section{Staphylococcus aureus}

Staphylococcus aureus causes food poisoning. Contamination usually originates from personnel handling food. The skin and mucous membranes of humans and animals are its normal habitat. However, insufficiently cleaned and sanitized process equipment can also be an important source of contamination. The bacterium can grow in improperly cooled foods such as chicken, ham, sausages, and pastry products, and it produces a toxin in the food which remains active even after heating up to $100^{\circ} \mathrm{C}$.

\section{Clostridium perfringens}

Clostridium perfringens, when ingested in large numbers, produces a toxin in the intestine. This food infection is often caused by consumption of meat and meat products that were not sufficiently heated to kill the fairly heat-resistant spores of this organism. Rapid cooling and cold storage of meat dishes that are not immediately consumed can prevent this food infection.

\section{Clostridium botulinum}

Clostridium botulinum, another anaerobic sporeforming bacterium, is a notorious food-poisoning organism. It produces a neurotoxin in foods with a $\mathrm{pH}$ above 4.5 , and outbreaks of botulism are characterized by high mortality rates (i.e., 30\%). Sterilized low-acid foods receive a "botulinum cook" to ensure elimination of the spores. Precooked chilled dishes are only heated to $75^{\circ} \mathrm{C}$ after packing and can present a hazard if not properly cooled during their entire shelf life.

\section{Bacillus cereus}

Bacillus cereus can give rise to two distinct types of food-borne disease, the emetic and the diarrhoeal syndromes. The emetic syndrome is believed to be associated with an emetic toxin preformed in the food. The symptoms are similar to those of Staphylococcus aureus intoxication. Cooked rice is often incriminated. The diarrhoeal type is caused by an enterotoxin and the symptoms are similar to those of Clostridium perfringens food poisoning. Bacillus cereus is a spore-forming organism, the spores being fairly heat resistant and their outgrowth is possible in a large variety of food products.

\section{Mycotoxigenic fungi}

Mycotoxigenic fungi are molds producing toxic substances when growing on food products. Notorious in this respect are Aspergillus flavus and Aspergillus parasiticus, producing the aflatoxins, secondary metabolites with carcinogenic properties. Molds used for food production are intensively studied for mycotoxin production, but so far no serious problems have been encountered. The occurrence of mycotoxins in plant products appears to be linked to extremes in weather conditions and an excessive occurrence of plague organisms in the growing season. The extreme dry growing seasons of 1988 and 1989 resulted in increased concentrations of aflatoxins in corn and peanuts in the United States.

\section{E. Prevention of Food-Borne Disease}

Factors that contribute to outbreaks of food-borne diseases are the consumption of contaminated raw foods (including seafood), inadequate cooling, inadequate heating, cross-contamination, and lapses of 12 hours or more between preparation and consumption. These are the principal factors for both food service establishments and homes. Major contributing factors associated with operations in foodprocessing plants are similar: contaminated raw ingredients, inadequate heat processing, improper cooling, contaminated persons handling foods, improper cleaning, and improper fermentation. There are many other factors that are a part of food protection schemes, but they appear to be of lesser importance.

\section{Fermentation}

The presence of high numbers of microorganisms in foods does not always indicate spoilage. Fermentation of foods involves the deliberate stimulation of part of the natural flora by providing conditions which favor its growth. These microorganisms might or might not still be present in the finished product, but the fermented food has usually ac- 
quired organoleptic (i.e., taste and small) properties which are widely different from the raw material.

Fermentation is one of the oldest methods of food processing. Some fermented products (e.g., cheese, yogurt, bread, beer, wine, and soy sauce) have experienced vast development and scale-up of production, including the use of intricate starter cultures. Others are still produced using age-old techniques under simple, even primitive, conditions.

For reasons of product integrity, taste and smell, and economics, most food fermentations cannot be performed profitably under strictly aseptic conditions. Fermented foods therefore can contain a variety of bacteria, yeasts, and molds originating from raw materials, process contamination, and inoculum. Not all of these organisms contribute positively to the desirable properties of the fermented product. In Table IV a number of fermented foods are listed, along with the microorganisms considered essential in their fermentation. In a number of examples (e.g., bread, beer, and some wines), the desirable fermentation can be achieved by a single microorganism. In others two or more species, with or without interactions, either simultaneously or in succession carry out a number of conversions, leading to the desirable properties of the final product.

TABLE IV Some Fermented Foods and the Important Microorganisms Involved

\begin{tabular}{|c|c|c|}
\hline Raw material & Microorganism & Product \\
\hline $\begin{array}{l}\text { Cereal } \\
\text { doughs }\end{array}$ & Saccharomyces cerevisiae & Bread \\
\hline Barley malt & Saccharomyces cerevisiae & Beer \\
\hline Milk & $\begin{array}{l}\text { Streptococcus thermophi- } \\
\text { lus, Lactobacillus } \\
\text { bulgaricus }\end{array}$ & Yogurt \\
\hline $\begin{array}{l}\text { Soybeans, } \\
\text { wheat flour }\end{array}$ & $\begin{array}{l}\text { Aspergillus oryzae, Asper- } \\
\text { gillus sojae, Zygosac- } \\
\text { charomyces rouxii, } \\
\text { Lactobacillus } \\
\text { delbrueckii, Pediococcus } \\
\text { halophilus }\end{array}$ & $\begin{array}{l}\text { Shoyu } \\
\quad(\text { soy sauce })\end{array}$ \\
\hline Soybeans & $\begin{array}{c}\text { Rhizopus oligosporus } \\
\text { lactic acid bacteria }\end{array}$ & Tempe \\
\hline Minced meat & $\begin{array}{l}\text { Lactobacillus spp., Pe- } \\
\text { diococcus spp., Micro- } \\
\text { coccus spp., Penicillium } \\
\text { chrysogenum, various } \\
\text { yeasts }\end{array}$ & Salami \\
\hline Herring & $\begin{array}{l}\text { Micrococcus spp., lactic } \\
\text { acid bacteria }\end{array}$ & Tidbits \\
\hline
\end{tabular}

An example of synergism occurs in yogurt, prepared from milk by fermentation with Lactobacillus bulgaricus and Streptococcus thermophilus. Lactobacillus bulgaricus is proteolytic and provides $S$. thermophilus with peptides and essential amino acids, whereas $S$. thermophilus stimulates the growth of $L$. bulgaricus by the production of formate from pyruvate under anaerobic conditions. As a result the rate of lactic acid production is much higher than predictable from the acid production rates of the individual cultures.

Soy sauce, or shoyu, is an example of fermented food produced in a two-stage procedure. In the first (koji) stage cooked soybeans and roasted wheat flour are inoculated with Aspergillus oryzae and Aspergillus sojae and incubated for 3 days. A variety of lytic enzymes are produced, which give rise to fermentable sugars, amino acids, and peptides. In the second (moromi) stage $18 \%$ sodium chloride is added, and the mass is allowed to ferment for 6-8 months at ambient temperatures. Microorganisms essential in this stage are Lactobacillus delbrueckii and Zygosaccharomyces rouxii.

In wine fermentation Saccharomyces cerevisiae is the dominant and most desirable organism. Other yeasts and lactic acid bacteria are usually involved, as no stringent conditions of asepsis or pasteurization are applied. At least in high-quality red wines, a second fermentation should follow the alcoholic fermentation. This malolactic fermentation is provoked by Leuconostoc oenos and results in less sour wines of milder taste, due to the conversion of malic acid into lactic acid and carbon dioxide. No great Bordeaux wines would exist without malolactic fermentation.

Modern fermentation technology calls for starter cultures with new and improved fermentation capabilities, such as can be realized with recombinant DNA techniques. Examples of genetic traits to be incorporated in lactic starter cultures are the production of chymosine (a milk-clotting enzyme), bacteriophage resistance, and enhanced cheese-ripening properties in starters for cheese. Important properties to be incorporated into yeast starter cultures are the ability to convert poorly fermentable dextrins for the production of low-calory "light" beer and $\beta$-glucan-degrading ability to alleviate filtration problems in the brewing industry. However, at present no genetically modified microorganisms are legally tolerated in food production, and public discussions about their acceptability have taken on global proportions. 


\section{Food Processing and Preservation}

Most bulk crops are harvested in seasons and in geographical areas, far away from the large contingents of consumers. This implies that storage over the seasons and transport over large distances must be possible. In addition, consumers' demands have evolved into the direction of ready-prepared food products with built-in convenience. For these reasons agricultural produce must be processed and stored under adequate conditions. A large number of processing and preservation methods are available for this purpose. Some of these aim at killing microorganisms and preventing recontamination (e.g., bottling or canning and subsequent pasteurization, sterilization, or irradiation). In other preservation methods the prevention or retardation of growth of microorganisms is pursued (e.g., in drying, salting, acidification, freezing, and cooling). Most of these operations are now carried out according to strict rules and specifications of hygiene as laid down in codes of practice describing good manufacturing practices, to ensure microbiologically safe products of high quality.

There are a number of interesting developments in food processing and preservation that deserve attention. High-temperature short-time processing and aseptic packaging have taken on gigantic proportions in the last two decades. Liquid foods (e.g., milk, fruit juices, and soft drinks) can be easily heat-processed in heat exchangers, allowing hightemperature short-time treatments. With increasing temperature the rate of killing of vegetative microorganisms and spores increases more rapidly than the rate of chemical reactions, leading to a loss of nutrients and general quality deterioration. Aseptic packaging in multilayered cartons and coextruded laminates has, to a large extent, replaced glass and metal containers for these products. New developments go into the direction of high-temperature short-time treatment and aseptic packaging of liquid foods containing particulates (e.g., soups).

Consumer demands for convenience foods have spurred the development of precooked chilled foods. After cooking, assembling, and packaging these meals are merely pasteurized for a few minutes at $75^{\circ} \mathrm{C}$, often by dielectric (i.e., microwave) heating. Since spores of nonproteolytic Clostridium botulinum can survive, one must rely on cold storage and distribution of these products below $4^{\circ} \mathrm{C}$ during the entire shelf life, to safeguard these products against growth and botulinum toxin production.
Modification of the gas atmosphere is increasingly used at various states of food manufacture and distribution, to the benefit of both producer and consumer. It partially provides an answer to the consumers' call for preservative-free foods. Carbon dioxide is the most effective gas for shelf-life extension, especially when combined with cooling. It extends the lag phase and decreases the growth rate of many, but not all, microorganisms. Lactic acid bacteria and Brochothrix thermosphacta are the dominant spoilage organisms in vacuum- and modified atmosphere-packed meats, stored under refrigeration.

Consumers' resistance toward preservatives such as benzoic acid and sorbic acid in products such as mayonnaise, dressings, and mayonnaise-based salads has led to the use of increased concentrations of food acidulants (e.g., acetic, lactic, and citric acids). However, because of sour taste, there are limitations to this practice, and a sufficiently long shelf life in cold storage can only be obtained by applying the most stringent rules of hygiene in the manufacture of these products.

Although emotionally rejected by the majority of the consumers, food irradiation is an effective process in reducing microorganisms in food products, extending shelf life and increasing food safety. In many countries food irradiation facilities have been installed. These usually contain a ${ }^{60} \mathrm{Co}$ source, emitting ionizing radiation, also called gamma radiation. The DNA in the bacterial cell is the primary target for radiation inactivation, while limited physical and chemical changes are induced in the food product.

The WHO has given approval for radiation dosages up to $10 \mathrm{kGy}$ as being unconditionally safe. The dose of $1 \mathrm{~Gy}$ is equivalent to $1 \mathrm{~J}$ of energy absorbed per kilogram of product. Irradiation at levels of $2-5 \mathrm{kGy}$ (i.e., radicidation) is effective in destroying salmonellae, campylobacters, and other non-spore-forming pathogens and could contribute much to reducing food infections from such products as raw meats and poultry. However, irradiated foods must be labeled as such and still find few buyers.

\section{Microbiological Control and Monitoring}

\section{A. Control}

Traditionally microbiological testing of foods has been focused on finished products. This was true 
for both the quality control laboratory of the manufacturers and the public health laboratories. The meaning of the data thus obtained depends largely on the sampling plan. However, due to the variable distribution of pathogens in foods, sampling plans are usually unsatisfactory. Consequently, it is often impossible to check for the absence of pathogens with reasonable confidence, no matter how rapid, accurate, and reproducible the microbiological analytical methods are. It has been recognized that massive microbiological routine testing is not a cost-effective approach to quality assurance.

The introduction in the 1970s of the hazard analysis critical control points concept has marked a change in philosophy toward the microbiological quality assurance of food. This concept provides a means for identifying the microbiologically important stages in a food operation and the means of their control. Introduction of this system starts with a detailed analysis of the hazards associated with the manufacture, distribution, and use of a food and leads to identification of the critical control points. Systematic and intensive monitoring and control are applied at these points. In applying these principles greater assurance of product safety is provided than would be possible with the traditional procedures.

Predictive food microbiology is an approach with respect to the prediction of shelf life and the microbiological safety of foods. Mathematical models and a data base are used to predict the microbiological status of a product of known composition and stored under a certain temperature regimen. The data base consists of data about growth and death of microorganisms, as measured in the laboratory under certain conditions of temperature, $a_{\mathrm{w}}, \mathrm{pH}$, etc. The conditions prevailing in the food are always different, but the models allow prediction of the likely outcome of conditions not specifically tested.

\section{B. Monitoring}

Routine microbiological testing used to be limited to enumeration of groups of microorganisms, followed by isolation and identification procedures for confirmation. These methods are time-consuming, rather tedious, and not fit for automation or on-line application. Also, they do not always provide us with information that is vital for proper judgment, such as the ability to produce toxin and the presence of toxin in food.
There have been rapid developments in techniques and instruments for the detection and enumeration of microorganisms that produce information faster than the traditional methods, as is required in modern quality assurance programs. The rapid techniques can be divided in those in which growth of microorganisms is required, usually taking 24 hours, and those in which cells are counted or metabolites are measured, directly in the product. Examples of the first group are impedimeters (Bactomatic, Princeton, New Jersey; Malthus, Stoke-on-Trent, United Kingdom), instruments which detect microbial activity by measuring changes in the electrical resistance of the growth medium. Other measuring principles applied in instruments of this category are nephelometry, radiometry, and microcalorimetry. In the second group direct counting can be done by direct epifluorescent filter techniques or by flow cytometry. In both techniques microorganisms are stained with a fluorescent dye or marker before microscopic counting. A successful direct method is the quantification of ATP of microbial origin by bioluminescence.

Other new approaches in the microbiological testing of foods are immunoassays and nucleic acid hybridizations. The application of enzyme-linked immunosorbent assays (ELISAs) is particularly successful in the detection of toxins (e.g., aflatoxins and staphyloenterotoxins) in food. ELISAs and latex agglutination kits for the detection of, for example, Salmonella spp. and L. monocytogenes, as well as various groups of fungi are now available. It is also possible to detect microorganisms or their virulence traits with DNA or RNA probes. As with the immunoassays, the DNA hybridization probes provide, in principle, any degree of specificity desired. In vitro DNA amplification with the aid of the polymerase chain reaction drastically increases the sensitivity of DNA probe detection. However, more research, especially on sample pretreatment, is required before DNA hybridization methods can be introduced into routine testing.

Food microbiologists and hygienists have the task of helping to reduce postharvest food losses and the incidence of food-borne disease. They must possess a thorough knowledge of the physiology and ecology of microorganisms in food and a good understanding of food science and technology in order to function optimally in the multidisciplinary team of food technologists that carries responsibility for providing the consumer with a continuous supply of wholesome and safe food. 


\section{Bibliography}

Bourgeois, C. M., Mescle, J. F., and Zucca, J. (eds.) (1988). "Microbiologie Alimentaire. Volume 1: Aspect Microbiologique de la Sécurité et de la Qualité Alimentaires." Lavoisier, Paris.

Bryan, F. L. (1988). Risks of practices, procedures and processes that lead to outbreaks of foodborne diseases. J. Food Prot. 51, 663.

Doyle, M. P. (ed.) (1989). "Foodborne Bacterial Pathogens." Dekker, New York.
Gould, G. W. (ed.) (1989). "Mechanisms of Action of Food Preservation Procedures." Elsevier, London.

Huis in't Veld, J., Hartog, B., and Hofstra, H. (1988). Changing perspectives in food microbiology: Implementation of rapid microbiological analyses in modern food processing. Food Rev. Int. 4, 271.

Jay, J. M. (1986). "Modern Food Microbiology," 3rd ed. Van Nostrand-Reinhold, New York.

Wood, B. J. B. (ed.) (1985). "Microbiology of Fermented Foods," Vols. 1 and 2. Elsevier, London. 